\title{
Levels of Stromal Derived Factor-1 (SDF-1) and Brain Derived Neurotropic Factor (BDNF) and Very Small Embryonic-Like Cells (VSEL) in Ischemic Stroke Patients
}

\author{
Bayu Winata Putera ${ }^{1,2, *}$, Cynthia R. Sartika ${ }^{2}$, Andi Wijaya ${ }^{1,2,3}$, \\ Irawan Yusuf ${ }^{1}$ and Aw Tar-Choon ${ }^{2,4}$
}

${ }^{1}$ Postgraduate Program in Clinical Biochemistry,
Hasanuddin University, Indonesia
${ }^{2}$ Prodia Stemcell Indonesia, Indonesia
${ }^{3}$ Prodia Clinical Laboratory, Indonesia
${ }^{4}$ National University of Singapore, Singapore
${ }^{*}$ Corresponding Author: bayu.winata@prostem.co.id

Received 22 February 2016; Accepted 8 March 2016;

Publication 25 April 2016

\begin{abstract}
Ischemic stroke remains a major health problem associated with high mortality and severe morbidity. The challenge of treatment is to understand the process leading to endogenous neurorepair mechanism to ischemic stroke. This study tested the hypothesis that VSEL, SDF-1 and BDNF have important roles in the process endogenous neurorepair in response to ischemic stroke. Studies indicated an increase in SDF-1 and VSEL within one week of stroke. BDNF levels tapered after day 15. Together the studies indicated that BDNF levels were highest when measured within 7 days of stroke onset and decreased thereafter. SDF-1 and VSEL were highest at between 7 and 15 days of stroke onset. The findings indicated that SDF-1 could be key for VSEL to be mobilized as a natural repair process whereas BDNF might be the correlative response to prevent cell death.
\end{abstract}

Keywords: SDF-1, BDNF, VSEL, Ischaemic stroke.

International Journal of Translational Science, Vol. 2016, 61-70.

doi: 10.13052/ijts2246-8765.2016.004

(C) 2016 River Publishers. All rights reserved. 


\section{Introduction}

Acute ischaemic stroke is a common problem that carries a significant risk of death and disability [1]. The incidence is approximately 12.1 per 1000 persons in the Indonesian population [2]. SDF-1 is the major chemoattractant for stem cells [3-6]. Very small embryonic-like cells (VSEL) is a population of stem cells identified in the bone marrow. Under steady-state conditions, VSEL circuculate at very low levels in peripheral blood [7].

Stroke can trigger mobilization of VSEL that could have prognostic value [8]. Additionally, patient prognosis can also be predicted by levels of brain-derived neurotrophic factor (BDNF). BDNF is a neurotrophic factor that plays an important role in controlling intercellular and intracellular signaling pathways that scuplt neuronal circuits during brain development and fundamentally regulate plasticity as well as cell survival in the adult brain [9]. BDNF was shown to impart anti-apoptotic effects after stroke to reduce infarct size and secondary neuronal cell death [10]. To this end, this study measured the levels of SDF-1, BDNF and VSEL in ischemic stroke patients at different time points following onset of stroke.

\section{Methods}

\subsection{Human Subjects}

We enrolled acute ischemic stroke patient in The Central Hospital of the Army (RSPAD), Gatot Subroto Jakarta. Blood was obtained following informed consent approval. The study was approved by the Institutional Review Board. The patients were divided into 3 groups. Group A $(n=11)$, patient with stroke onset less than 7 days ( $<7$ days), group $B(n=12)$, patient with stroke onset between $7-15$ days and group $C$ patient $(n=12)$ with stroke onset more than 15 days. Diagnosis of ischemic stroke was made using clinical examination and magnetic resonance imaging (MRI) followed by interpretation by a staff neurologist.

\subsection{Cytokine Quantitation}

SDF-1 and BDNF levels from serum were measured using multiplex method with Luminex Magpix instrument (Bio-Rad). VSEL was quantified using flowcytometry (BD Biosciences, FacsCanto). 


\section{Result}

Table showed the characteristics and normality test of 51 patients. The mean minimum and maximum values for SDF-1, BDNF and VSEL are also shown with the mean \pm SD noted in the right colum.

Figure 1 showed the highest levels of SDF-1 in Group B (81 pg/ml). This correlated with an increase in VSEL (Figure 3). A similar finding with regards to correlation between SDF-1 and VSEL was reported for patients within 7-15 days of onset of stroke [8]. VSEL comprise a population of stemcells with embryonic stem cell like cell capability and may constitute the most primitive population of stem cells in bone marrow [11]. On the basis of this finding, it was postulated that a population of VSEL respond robustly to a levels of SDF-1. This chemokine is upregulated in a hypoxia-dependent manner in damaged organs [10]. It is postulated that VSEL would home to the damaged organs or tissues in an attempt to contribute to regeneration [10, 12].

In a murine model of stroke, Kucia et al. [13] reported on an increase in SDF-1 during the first week following stroke. Our study showed that in period 7-15 days following onset of stroke, SDF-1 levels and VSEL numbers are highest, indicating that VSEL cells are mobilized into peripheral blood in the highest numbers during this period and is accompanied by higher levels of SDF-1 during this time.

Table 1 General characteristics of subjects and normality test $(\mathrm{n}=51)$

\begin{tabular}{lccc}
\hline Variable & Min & Max & Mean \pm SD \\
\hline Age $($ Year $)$ & 38 & 79 & $59.6 \pm 10.78$ \\
SDF-1 $(\mathrm{pg} / \mathrm{mL})$ & 16.78 & 181.7 & $73.61 \pm 32.13$ \\
BDNF $(\mathrm{pg} / \mathrm{mL})$ & 6,105 & 28,781 & $16079 \pm 5356.50$ \\
VSEL $\left(10^{3}\right.$ cells/ml $)$ & 1.62 & 746 & $58.42 \pm 112.06$ \\
\hline
\end{tabular}

SDF-1: Stromal Derived Factor-1; BDNF: Brain-Derived Neurothropic Factor; VSEL: Very Small Embryonic-Like Cells.

Table 2 Comparison of biomarkers among groups

\begin{tabular}{lccc}
\hline \multirow{2}{*}{ Clinical } & \multicolumn{3}{c}{ Subject Onset Group* } \\
\cline { 2 - 4 } Characteristics & (A) $<7$ Days & (B) 7-15 Days & $($ C) $>15$ Days \\
\hline Age $($ year $)$ & After Onset & After Onset & After Onset \\
SDF-1 $(\mathrm{pg} / \mathrm{ml})$ & $61.54 \pm 10.09$ & $58.66 \pm 10.76$ & $58.36 \pm 9.42$ \\
BDNF $(\mathrm{pg} / \mathrm{ml})$ & $18.68 \pm 21.23$ & $81.00 \pm 42.01$ & $64.49 \pm 29.25$ \\
VSEL $\left(10^{3}\right.$ cells $\left./ \mathrm{ml}\right)$ & $44.08 \pm 30.17$ & $79.092 \pm 5599.40$ & $13,437 \pm 3978.14$ \\
\hline
\end{tabular}




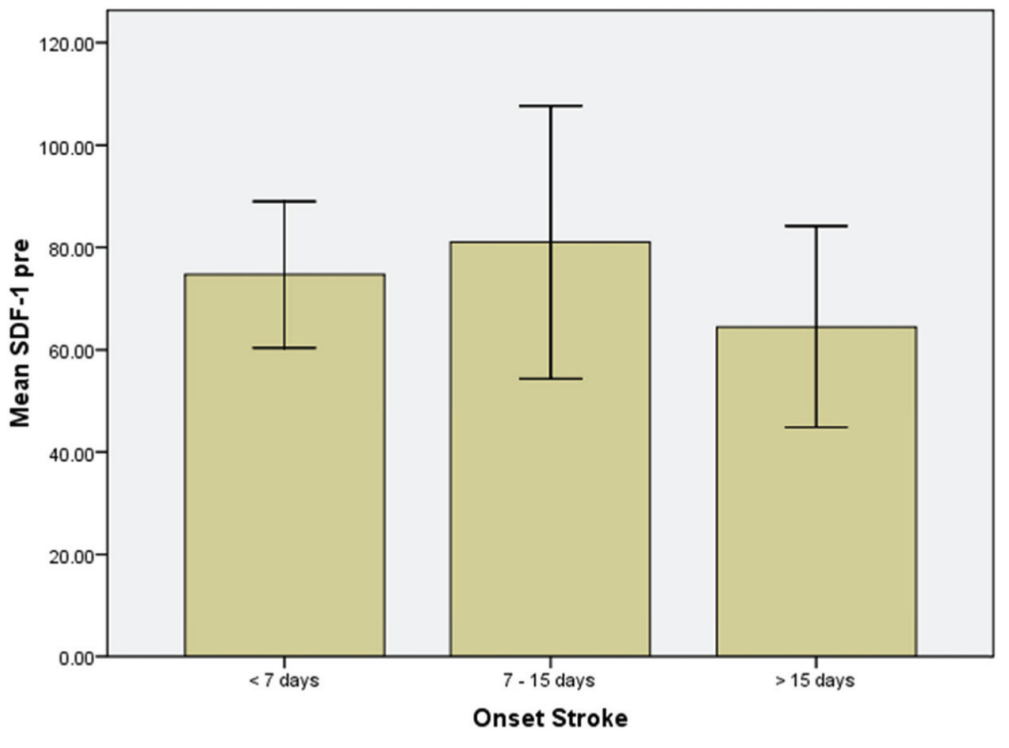

Error Bars: $95 \% \mathrm{Cl}$

Figure 1 Graph of SDF-1 levels in stroke patients.

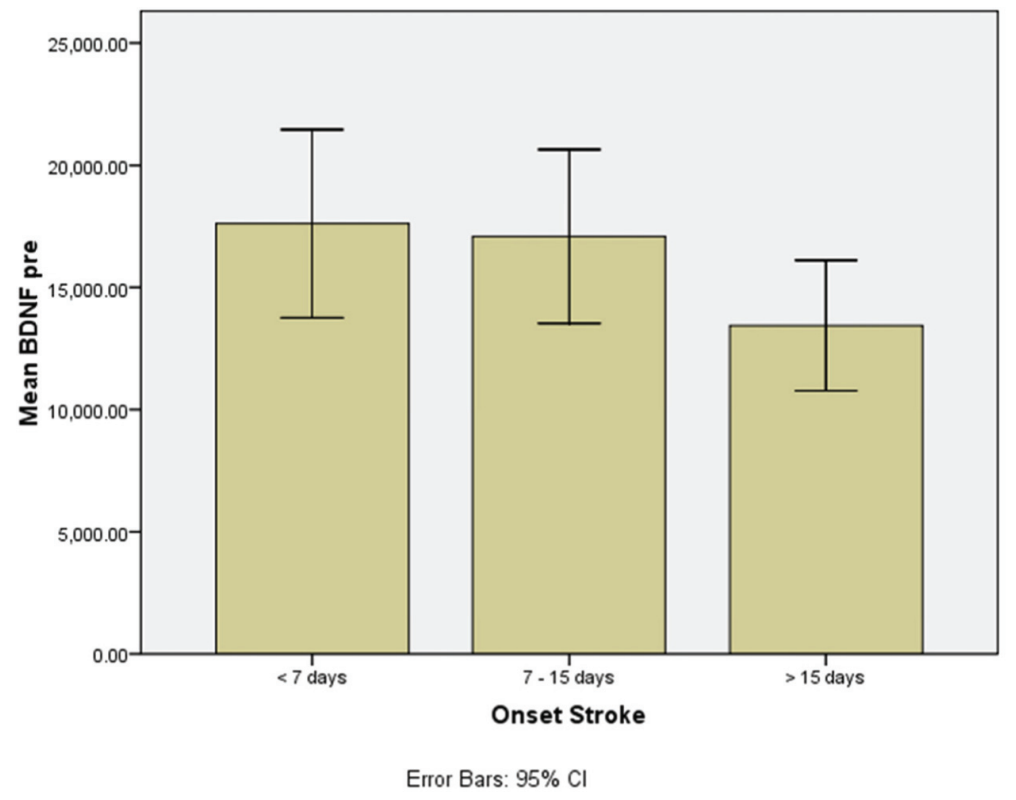

Figure 2 Graph of BDNF levels in stroke patients. 




Figure 3 Graph of VSEL levels in stroke patients.

Our study further showed that levels of BDNF was the lowest in group $\mathrm{C}$ (patient with onset of stroke $>15$ days). BDNF is involved in neuronal survival, sypnatic plasticity [10]. Furthermore, BDNF has been shown to have antiapoptotic action after stroke [10]. BDNF can also contribute to recovery of skills after focal ischemia in rats and enhances poststroke sensorimotor recovery and stimulates neurogenesis [10]. Thus, the levels of BDNF remain high so that it can contribute to recovery after stroke. This is a preliminary case report and we plan to expand this study to monitor the same patient over time following onset of stroke to better understand the dynamics of these parameters following onset of stroke. Such understanding of the dynamic interplay of the parameters will allow us to better predict and develop methods to improve outcome in stroke patients.

\section{Acknowledgement}

We wish to thank Prodia StemCell Indonesia (ProSTEM) and Prodia Education and Research Institute (PERI) for their support of this study. 


\section{References}

[1] Benatar M. 2005. Heparin use in acute ischaemic stroke: does evidence change practice? Q J Med. 98: 147-152.

[2] Kementerian Kesehatan Republik Indonesia. 2014. Laporan Riset Kesehatan Dasar (RISKESDAS) 2013.

[3] Netelenbos T., Zuijderduijn S., van den Born J., Kessler F. L., Zweegman S., Huijgens P. C., et al. 2002. Proteoglycans guide SDF-1 induced migration of hematopoietic progenitor cells. J. Leukocyte Biol. 72: 353-362.

[4] Kim, C. H., and Broxmeyer, H. E. 1998. In vitro behavior of hematopoietic progenitor cells under the influence of chemoattractants: stromal cell-derived factor-1, steel factor, and the bone marrow environment. Blood 9: 100-110.

[5] Siegenthaler J. A., and Pleasure S. J. 2010. There's no place like home for neural stem cell. Cell Stem Cell 7: 141-143.

[6] Castellanos M., Sobrino T., and Castillo J. 2006. Evolving paradigms for neuroprotection: molecular identification of ischemic penumbra. Cerebrivasc. Dis. 21(suppl 2): 71-79.

[7] Kucia M. J., Wysoczynski M., Wu W., Zuba-Surma E. K., Ratajczak J., and Ratajczak M. Z. 2008. Evidence that very small embryonic-like stem cells are mobilized into peripheral blood. Stemcells 26: 2083-2092.

[8] Paczkowska E., Kucia M., Koziarska D., Halasa M., Safranow K., et al. 2009. Clinical evidence that very small embryonic-like stem cells are mobilized into peripheral blood in patients after stroke. Stroke 40: 12371244.

[9] Mattson M. P., Maudsley S., and Martin B. 2004. BDNF and 5-HT: a dynamic duo in age-related neuronal plasticity and neurodegenerative disorders. Trends Neurosci. 27: 589-594.

[10] Schabitz W.-R., Steigleder T., Cooper-Kuhn C. M., Schwab S., Sommer C., Schneider A., and Kuhn G. 2007. Intravenous brain-derived neurotrophic factor enhances poststroke sensorimotor recovery and stimulates neurogenesis. Stroke 38: 2165-2172.

[11] Ratajczak M., Zuba-Surma E. K., Ratajczak J., Wysoczynski M., and Kucia M. 2008. Very small embryonic like (VSEL) stem cells characterization, developental origin and biological significance. Exp. Hematol. 36: 742-751.

[12] Ceradini D. J., Kulkarni A. R., Callaghan M. J., Tepper O. M., Bastidas N., Kleinman M. E., Capla J. M., Galiano R. D., Levine J. P., and 
Gurtner G. C. 2004. Progenitor cell trafficking is regulated by hypoxic gradients through HIF-1 induction of SDF-1. Nat. Med. 10: 858-864.

[13] Kucia M., Zhang Y. P., Reca R., Wysoczynski M., Machalinski B., Majka M., Ildstad S. T., Ratajczak J., Shields C. B., and Ratajczak M. Z. 2006. Cells enriched in markers of neural tissue-committed stem cells reside in the bone marrow and are mobilized into peripheral blood following stroke. Leukemia 20: 18-28.

[14] Ploughman M., Windle V., MacLellan C. L., White N., Dore J. J., and Corbett D. 2009. Brain-derived neurotrophic factor contributes to recovery of skilled reacjing after focal ischemic in rats. Stroke 40: 1490-1495.

\section{Biographies}

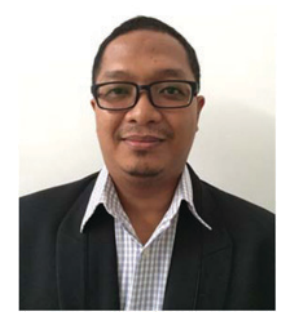

B. W. Putera holds a pharmacist at Padjadjaran University, Indonesia in 2006 and finished his Master from Hasanuddin University, Indonesia. He also actively involved in various research especially at the field of clinical chemistry and stem cells. He have many publication of papers: The Dynamic roles of Visfatin and Obestatin Serum Concentration in Pancreatic Beta Cells Dysfunction and Insulin Resistance in Centrallly Obese Men where published in Indonesian Biomedical Journal, Factors Affecting The Acquisition of CD34 Cells From Umbiical Cord Blood where published in American Journal of Scientific Research. 


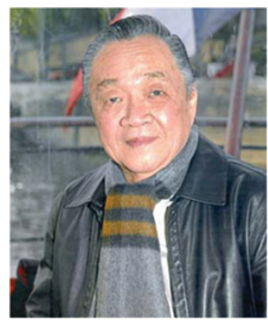

A. Wijaya holds a pharmacist at Institute Technology Bandung, Indonesia in 1963 and finished his Ph.D in 1978 from University of Munster, Germany. He have many award from many organization: Golden Academy Award from National Academy of Clinical Biochemistry USA in 1987, doctor honoris causa in biomedical science from University of Birmingham in 1991, Hold Record of Achievement in Science from NACCCA, USA in 1994. He also actively involved in various research and development activities especially in the field of clinical chemistry and stem cell. Many scientific articles, papers, and research that related to the field of clinical chemistry and stem cells have been written by him.

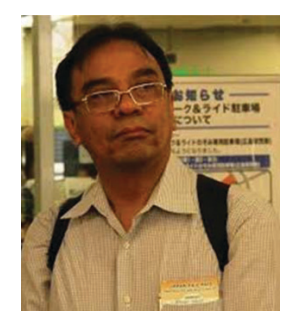

I. Yusuf holds a medical doctor degree at Medical Faculty of Hasanuddin University Makassar in 1984 and finished his Ph.D in 1992 from Hiroshima University School of Medicine, Japan. He is a lecturer at department of Physiology since 1986. He also actively involved in various research and development activities, especially in the field of molecular biology. He was doing research on Cellular Electrophysiology of Cardiac Cell Membrane (1987-1992) and also a Senior Researcher at the Eijkman Institute, Jakarta (1995-2002). Many scientific articles, books, papers, and research that related to the field of molecular and genetics have been written by him. He was a pioneer of International Class for Malaysian students and Faculty of Psychology at Hasanuddin University. He has been awarded with "2013 Bakrie Award" for his achievement in research. 


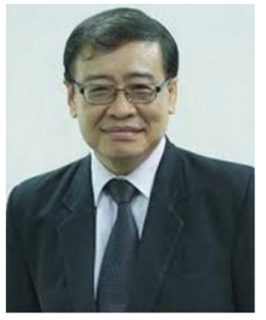

Aw Tar-Choon is expertis in the field of clinical chemistry and stem cells. He holds a medical doctor degree at University of Malaya and his Master in Harvard-National University of Singapore in 1992. He is a lecturer at University of Singapore, Singapore. He also actively involved in various research and development activities, especially in the field of clinical chemistry, endocrinology, stem cells and health policy. Many scientific articles, books, papers, and research that related to the field of research and development activities, especially in the field of clinical chemistry, endocrinology, stem cells and health policy have been written by him. He have many award from many organization: American Academy of Clinical Laboratory Physicians and scientist young investigator award in 1982 and 1983, BoehringerMannheim gold medal by Singapore Association of Clinical Biochemist in 1988, Becton-Dickinson award from Singapore Society of Pathology in 1996. 
